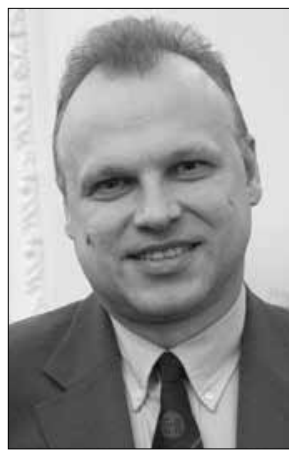

https://doi.org/10.24101/logos.2019.44

Gauta 20190320

\title{
EUGENIJUS DANILEVIČIUS
}

Vytauto Didžiojo universitetas, Lietuva

Vytautas Magnus University, Lithuania

\section{PERSONALISTINÉ VILTIES PEDAGOGIKA: PAGRINDINIAI KONCEPTUALŪS BRUOŽAI}

\author{
Personalistic Pedagogics of Hope: \\ The Main Conceptual Features
}

\begin{abstract}
SUMMARY
The article defines the main conceptual features of a personalistic pedagogics of hope. The article introduces the main conclusions of theoretical research: 1) Personalistic pedagogics of hope consists of three elements - personalism, hope and pedagogics, and meaning is common to both. As an expression of human opportunities, hope gives a meaning to pedagogical activity. Personalism and pedagogics have the common aim of finding meaning. Therefore, meaning is the foundation of the synthesis of personalism, hope and pedagogics, and the most important segment of personalistic pedagogics of hope. The theory of logotherapy also emphasizes the significance of hope for a person looking for the meaning of life and implementing it. 2) A dramatic situation of the world nowadays (and in the future) requires a message of hope. In the face of difficult challenges and dangers, hope is not a stimulus to simply calculate chances and dangers, but a human response to them. On a human level, such a tendency is obvious: the more Christian hope loses its position in a society, the more illusory hopes or despair grow in hat society. Thus, the need to bear witness to Christian hope is clear. The main goal of personalistic pedagogics of hope - the education of the virtue of hope - is directed that way.
\end{abstract}

\section{SANTRAUKA}

Siekiant apibūdinti personalistinės vilties pedagogikos pagrindinius konceptualius bruožus, straipsnyje atliekama pedagoginès, filosofinès ir teologinès mokslinės literatūros teorinè sisteminė turinio analizė ir sintezè, kurių pagrindu aptariama personalistinès vilties pedagogikos samprata ir formuluojamas šios krikščioniškosios pedagogikos šakos pagrindinis tikslas. Straipsnio pabaigoje pateiktos teoriškai pagrịstos šio tyrimo išvados. 


\section{IVADAS}

Lietuvos visuomenëje įsigalint nevilties kultūrai, globalizacijos, finansinès ar visuomeninès krizès sukeltų staigių neigiamų permainų akivaizdoje viltis tampa žmogaus gyvenimo pagrindu. Vilties klausimas ypač aktualus, kai žmogus patiria sunkumu, yra gundomas dvasiškai palūžti ir nepajègia pažvelgti i savo ateiti, kai galiausiai pasiduoda apgaulei ar susižavi utopinemis ateities vizijomis. Asmuo savo esybe negali priimti ir susitaikyti su beviltiškumu, nes žmogui būdingas geresnès ateities ir visuomeninès tvarkos ilgesys, kuri apibūdina i jo prigimti irašyta viltis nugalèti vargus, kančias, nuovargi ar net mirti. Viltis, kuri aiškiai kreipia i tvarką ir tobuluma, leidžia žmogui nekapituliuoti prieš gyvenime pasitaikanti chaosą ir netvarką, sudaro sąlygas rasti vidinių krizių sprendimų. Nevilties kultūros keliamų iššūkių akivaizdoje viltis pasireiškia ne kaip pasyvus požiūris ị ateiti, pasyvi rezignacija ar susitaikymas su viskuo, ką atneša kasdienybe, o kaip konkretus veikimas su meile kuriant ateití. Turèti vilti - tai būti atsigręžusiam ị tiksla, kuris yra kilęs ne iš paties žmogaus. Tai atsakymas begalinei Būčiai i̇ sukūrimą. Tai būdas žmogui ieškoti Dievo, kuris yra jo žmogiškosios vilties Garantas. Dieviškoje viltyje gali sutilpti konkreti žmogaus viltis. Būtent viltis padeda žmogiškajai būčiai įsišaknyti ateityje. Tai viltis visiems ir su visais. Visa sukurtoji tikrovè - žmonių darbai, kultūra ir gamta - patvirtina viltị keliančią Dievo kuriančiąją meilę. Personalistinè vilties pedagogika savo esme yra orientuota $i$ vilties dorybès ir vilties žmonių ugdymą meilès dialogu.
Viltis siejama ne tik su ateitimi, nes turi palaikomosios ir kuriamosios itakos dabarčiai. Vertindamas dabarties įvykius žmogus, remdamasis viltimi, tikisi, kad tai, kas dabar vyksta, ilgalaikëje perspektyvoje ji veda i didesni gèri. Šiuo aspektu vilties dorybė pedagoginėse veiklose ne tik nubrèžia teorini tikslą su meile kurti ateiti, bet turi ir ugdomąą vertę, nes jau dabar kreipia ugdytinio gyvenimą i gèrị. Vilties dorybès ugdymas pedagogikoje yra svarbus uždavinys.

Personalizmo pateikiami pagrindiniai žmogaus asmens bruožai, tiesa apie ji patị ir pagrindiniai tarpasmeninio santykio postulatai personalistinei vilties pedagogikai teikia metodologini pagrindą. Personalistinè vilties pedagogika remiasi nuostata gyvenimo pasirinkimuose vadovautis tiesa apie žmogų tiesa, kuri būtų gyvenimo prasmės šaltinis ir motyvas užsiimti saviugda, tvirtintų nekvestionuojamą ir neredukuojamą žmogaus vertę, besąlygišką jo orumą. Tokią tiesą apie žmogų skelbia personalistinè žmogaus koncepcija. Šiuo aspektu vilties dorybės ugdymas yra nukreiptas i žmogiškumo vertès pripažinima, pagarbą jai ir jos igyvendinima, i saviugda, savęs tobulinimą ir asmeninị išsiskleidimą.

Žmogui ugdantis vilties dorybę reikia nuolat atsinaujinti ir tobulèti, nes dabartinis laikas atsiskleidžia kaip akimirka, pasak šv. Jono Paliaus II, paženklinta „,vilties užtemimu“, kuriam būdinga tai, kad „daugelis vyrų ir moteru atrodo praradę orientyrus, netikri, be vilties, ir tokia dvasios būsena taip pat nesvetima ne vienam krikščioniui. Trečiojo tūkstant- 
mečio pradžioje Europos žemyno horizontą temdo daug nerimą keliančiu ženklų“ (Jonas Paulius II 2003: § 7). Tai parodo, kodèl svarbu dèti pastangas, kad šių dienų žmogus pažintų tiesą apie save pati bei savo prigimti ir kad remdamasis šia tiesa galètų ugdytis jègų teikiančią vilti gyventi.

\section{PERSONALISTINĖS VILTIES PEDAGOGIKOS SAMPRATA}

Pedagogika žmogui padeda atskleisti ir igyvendinti tai, kas jame yra geriausio, ir parodo jo žmogiškumą. Viena iš pedagogikos funkciju, nukreiptų i vilties ir kitų dorybių ar vertybių ugdyma, yra auklejjimas. Popiežiškoji dvasinių pašaukimų globos draugija pateikia tokias auklèjimo charakteristikas: „Auklejjimas (lot. educatio) etimologine žodžio prasme reiškia ištraukti i paviršių (e-ducere) jo turimą tiesa, tai, kas yra jo širdyje, net tai, ko jis pats nežino apie save, būtent jo silpnybes ir lūkesčius, stengiantis skatinti jo atsako i pašaukimą laisvę. <...> Auklējimas vykdomas šiomis kryptimis: savižinos, slèpinio prièmimo, mokejjimo aiškinti gyvenimą ir šaukimosi (e-vocare). <..> Auklejjimas - tai jauno žmogaus skatinimas pažinti save, pašaukimo charizmoje nepaliaujamai ieškoti savo tapatybès bei jo paruošimas priimti save kaip iki galo nepažistamą slèpini, nes „slèpinio pajautos netektis yra viena didžiausių pašaukimų krizès priežasčių" (Popiežiškoji dvasinių pašaukimu globos draugija 1999: § 35). Personalistinè vilties pedagogika remiasi aktyvia dinamine žmogaus prigimtimi: jaunas žmogus ugdosi gebejjimą ieškoti kelių, vedančių i tikslą. Taip formuojasi įsitikinimas, kad artimesnejje ar tolimesnèje ateityje iškils naujų svarbių iššūkių, kuriems spręsti prireiks išugdytų dorybių, pozityvių vertybių ir universalių gèrių. I šs dinamini žmogaus dvasinio gyvenimo bruožą yra irašyta viltis, kuri motyvuoja asmeni siekti kilnių tikslų, suteikdama jiems prasmę, ir mobilizuoja valią nuolat dirbti ir veikti, kad būtuc pasiekta asmeninių ir visuomeninių gèrių. Ši viltis ne turi konkretu laika, o priklauso konkrečiai erdvei, laikui ir veiksmui.

Viltis, apibrěžta kaip žmogaus galimybių išraiška, teikia mokslinei (taip pat pedagoginei) veiklai prasmę. Personalizmas akcentuoja žmogaus veiklos ir gyvenimo prasmès svarbą: „Ugdomasis darbas yra galimas tik tada, kai yra suvokiama žmogaus gyvenimo prasmè ir jo buvimo tikslas. Pirma negu pradedama ugdyti, reikia žinoti, kam ugdyti“ (Maceina 1991: 125). Pedagogikos svarbiausios funkcijos - ugdymo - pagrindinis tikslas yra "parengti žmogų savarankiškam ir prasmingam gyvenimui“ (Pukelis 1998: 52). Bendras rūpestis gyvenimo prasmės atpažinimu jungia personalizmą su pedagogika. Apibendrinant galima teigti, kad prasmé sujungia tris elementus - personalizma, vilti ir pedagogi$k q$ - ir sudaro nedaloma visuma - personalistine vilties pedagogika.

Viena vertus, viltis yra žmogiškai paprasta ir remiasi intuicija, antra vertus, neprieštarauja protui ir racionaliam ịvykių prognozavimui. Viltis yra nukreipta i konkretu tikslą ir remiasi tikejjimu, kad tikslas bus pasiektas. Vis dèlto, jei žmo- 
gui jis atrodo per sunkiai pasiekiamas, viltis ima silpti nors, objektyviai vertinant, šis tikslas išlieka realus ir pasiekiamas, tik reikalauja ypatingu pastangų. Pedagogika, kaip mokslas apie jauno žmogaus ugdymą ir ugdymąsi, akcentuoja potencialo ir galimybiu atskleidimo vaidmenį: asmuo skleidžiasi savo pašaukimo perspektyvoje, o ne determinuotoje priklausomybejje nuo likimo nulemtų aplinkybių. Transcendentinis potencialas peržengti pati save, apibūdinantis asmeninę būti, yra nukreiptas i i igyvendinimą. Nepriklausomai nuo reikalavimu, kuriuos asmeniui kelia profesija, personalistinè vilties pedagogika turi būti nukreipta i žmogaus savęs pažinimą savo igimto orumo interiorizaciją ir savo žmogiškumo išskleidimą.

Šiuolaikinèje visuomenëje žmogus turi galimybių aktyviai reikštis įvairiose veiklose. Žmogaus, kaip bendruomeninès ir dvasinès, kartu ir gamtinès bei kultūrinès, religingos būtybès, vystymasis yra susijęs su visuomene, kultūra ir religija. Viena vertus, asmuo, priimdamas ir interiorizuodamas kultūrą ir religija, praturtèja pats, kita vertus, remdamasis amžinosiomis vertybėmis, žmogus kuria, keičia ir turtina visuomenès kultūrą. Šiame visuomenès ir asmenybès kūrimosi ir tobulejimo procese dalyvauja viltis.

Personalistinė vilties pedagogika siekia apimti žmogaus būties visumą. Ši pedagogika remiasi antropologijos, filosofijos, psichologijos, teologijos ir kitų mokslų izžvalgomis apie žmogų ir siekia optimalaus ugdymo tikslų ir idealu igyvendinimo bei asmens savirealizacijos. Šiuolaikinès pedagogos kryptys skirtin- gai interpretuoja vilti ir jos svarbą ugdymui. Analitinè empirinè pedagogikos kryptis nesuteikia vilčiai racionalaus pagrindo ir traktuoja ją kaip utopiją. Empirinès krypties pedagogikoje ugdymo pagrindas yra analitinio kritinio mąstymo lavinimas, o rengiant pedagogus, išskiriami šie pagrindiniai dalykai: švietimo filosofija, pedagogikos istorija, pedagoginè psichologija arba sociologija, ir akcentuojamas analizès metodas bei juo gristas analitinis kritinis mąstymas, mokytojo pedagoginei veiklai suteikiantis pagrindinę metodologinę krypti.

Vienas iš kritinès pedagogikos kūrèjų ir atstovu yra P. Freire'as (1921-1997), kuris vilties pedagogikos analizei skyrè pagrindinę vietą. Savo pedagogikos teorijoje jis bande suderinti viena kitai prieštaraujančias pasaulěžiūrą formuojančias sroves: marksizmo ideologiją ir krikščioniškąją doktriną. Marksizmo ideologija iš esmès prieštarauja personalistinei vilties pedagogikai, tačiau šio autoriaus darbuose galima rasti personalistinę vilties pedagogiką pagrindžiančių teiginių. Šis kritinès pedagogikos kūrèjas vilti iškelia kaip būtiną ugdymo sąlygą: „Be vilties neįmanoma net pradèti mąstyti apie ugdymą" (Freire 2007: 87). Šio pedagogikos mokslininko atstovaujamos kritinės pedagogikos kontekste viltis teikia pagrindą kritikuoti ugdymo proceso institucionalizavimą ir deindividualizavimą. Personalistinei vilties pedagogikai taip pat yra svarbus P. Freire'o suformuluotas kritinès pedagogikos teiginys, kad pedagoginis mąstymas pirmiausia turi pasižymèti vilties kalba, o ne reprodukcijos teorijos retorika (Freire 2007: 87). 


\section{PAGRINDINIS PERSONALISTINĖS VILTIES PEDAGOGIKOS TIKSLAS}

Žmogaus samprata, grindžiama besąlygiška žmogaus verte ir jo išsiskleidimu kuriant gèrị savyje ir būnant gèriu kitiems - tai žmogaus kaip asmens koncepcija. Ja remdamasi, personalistinè vilties pedagogika teikia pagalbą dvasiškai tobulejjančiam žmogui. Žmogus kaip laisva, protinga, nuolat besikurianti ir atsakinga būtybė, kuriai priklauso besąlyginis orumas, reikalauja galimybès aktualizuoti, išreikšti nesavanaudišką pagarbą ir meilę - tai igyvendinama save dovanojant bendrajam gèriui kurti. $\breve{S}_{i}$ pagarba ir meilè geriausiai išreiškiama bendruomenèse, neatimančiose iš savo narių laisvės ir sukuriančiose kiekvienam sąlygas vystytis kaip asmeniui.

Vilties dorybès, kaip igimto polinkio, ugdymas iš esmès skiriasi nuo optimizmo ar pozityvaus mąstymo, kaip išmoktų dalykų, lavinimo. Kadangi vilties dorybès ugdytojas yra vertybiu liudytojas, be to, gyvenimo jomis pavyzdys, jis daro poveikị būtent savo autentišku elgesiu, šiuo atveju - sava viltimi.

Pagrindinis personalistinés vilties pedagogikos tikslas yra ugdyti vilties dorybę. Jis reikalauja gebėti kurti meilès dialogą, ilgalaikius planus ir gyvenimo projektus, staigiai ir adekvačiai reaguoti i pokyčius, mokytis pozityviai žvelgti i gyvenima, priimti svarbius sprendimus, apsispręsti, ugdyti pozityvų požiūrị i ateití, pasauli ir save. Vilties ugdymas turi vykti kartu su viso asmens tobulëjimu, t. y. besąlygišku žmogaus asmens orumo pripažinimu, tikèjimo sąmoningumo augi$\mathrm{mu}$, kuriančiosios meilès stiprèjimu, pašaukimo atpažinimu ir vykdymu, gy- venimo prasmès suradimu, neikainojamos savo ir kitų žmoniu gyvenimo vertés supratimu bei ateities meile.

Ugdant vilties dorybę išryškëja dvi grupès veiksnių: 1) teigiami, kuriantys ir stiprinantys viltị; 2) neigiami, silpninantys ir žlugdantys viltị (šie veiksniai oponuoja ir neigia vilties argumentus, dažnai klastoja ar sukarikatūrina autentišką katalikiškosios vilties sampratą).

Teigiami vilties dorybès ugdymo veiksniai yra nukreipti $\mathfrak{i}$ žmogiškosios būtybès sąmoningumo stiprinimą. Jie remiasi žmogaus koncepcija, kuriai būdingas besąlygiškos žmogaus ir žmoniškumo vertès supratimas, prièmimas ir pripažinimas - tai suteikia gyvenimui esminę prasmę ir pagrindžia vilties būtinybę žmogaus gyvenime. Taigi, pagrindinis vilties dorybès ugdymo metodas yra pedagoginès sąveikos, vykstančios meilès dialogo atmosferoje, kuriamas asmeninis santykis su žmogumi, kuris yra vilties žmogus, kasdien ja vadovaujasi ir sugeba ją patvirtinti savo gyvenimo pavyzdžiu. Šis metodas yra pagrindinis ne tik ugdant vilties dorybę, bet ir perduodant kitas vertybes. Tiesioginis asmeninis kontaktas su liudytoju, kuris gyvena vadovaudamasis tam tikra vertybe, dorybe ar moraline nuostata, yra veiksmingiausia pedagoginè priemonè. A. Komenskis teigia, kad „Žmones išmintingus padaryti gali tik išmintingasis, iškalbingus - iškalbingasis, dorus - dorasis“ (Komenskis 1975: 587). Paulius VI akcentuoja pedagoginę liudijimo vertę: „Šiandienis žmogus mieliau klauso liudytojų, ne mokytojų, o jei klauso moky- 
tojų, tai dèl to, kad jie yra liudytojai" (Paulius VI 1975: § 41). Personalistinès vilties pedagogikoje efektyvus yra ir didaktinis pasakojimo metodas: pateikiama gyvenimo istorijų su pavyzdžiais, patvirtinančiais vilties dorybės gelbstintị poveiki sudètingų situacijų ar problemų akivaizdoje. Šie realūs pasakojimai apie šventųju, kitų žmonių arba grožinès literatūros personažų ypatingą vilties liudijimą dažnai ilgam išlieka mokinių atmintyje ir tampa kertine atrama jiems patekus į sunkias, net beviltiškas situacijas. Sprendžiant su vilties netektimi susijusias problemas, personalistinès vilties pedagogikoje gali būti taikomas problemų sprendimu grindžiamas mokymo(si) metodas.

Neigiami vilties dorybès ugdymo veiksniai ypač suaktyvëja paauglysteje, išgyvenant identiteto formavimosi arba vaidmenu sumaišti (Erikson 2004: 308). Pagal šiam amžiui būdingas ypatybes jaunas žmogus dažnai būna susiformavęs nerealiai didelių vilčių. Vilties dorybès ugdymas susiduria su ypatingu iššūkiu padèti susigrąžinti viltị jaunuoliams, kurie turejjo didelių, nerealiais lūkesčiais gristų, iliuzinių vilčių ir jomis nusivylè, kurie po neišvengiamų ir dramatiškų nusivylimų nebejaučia gyvenimo prasmès, netenka energijos ir drąsos ginti amžinąją viltị ir vadovautis ja gyvenime. Tokia jaunų žmonių situacija visuomenèje igauna didžiuli masta, yra grèsminga ir reikalauja vilties dorybès ugdytoju ypatingu pastangu bei auklèjamųju veiksmų, nes šiuolaikinè masinè kultūra itteigia jaunam žmogui suprimityvintus gyvenimo sẻkmès pavyzdžius, subanalintus žmonių ryšių modelius bei nerea- lius iliuzinės vilties objektus ir kaip pagrindinį tikslą iškelia materialias gèrybes. Daugeliui jaunų žmonių tokia perspektyva nepasiekiama, nes jie gyvena nedarbu grasinančioje, materialinį ir kultūrinį skurdą reprodukuojančioje, gyvenimą destabilizuojančioje aplinkoje ir rizikuoja netekti prasmès ir vilties. Popiežius Pranciškus pažymi, kad jaunimo ugdymas yra veikiamas socialinių permainų, todèl „Jaunimas ipprastinèse struktūrose dažnai nesuranda atsakymų i savo rūpesčius, poreikius, problemas ir žaizdas", o ugdytojams, ypač vyresnès kartos atstovams, „sunku kantriai įsiklausyti, suprasti jų rūpesčius ir prašymus, išmokti kalbètis su jais jiems suprantama kalba" (Popiežius Pranciškus 2014: § 105).

Vilties dorybès ugdytojams, dirbantiems su jaunais žmonėmis, yra keliamas siekinys atskleisti jiems amžinosios vilties svarba, skatinti juos nuolat stiprinti vilti, statyti ją ant tiesos, laisvès ir atsakomybės pamatų. Šiame kontekste išsikristalizuoja keletas personalistinés vilties pedagogikos uždaviniu: 1) mokyti atsargaus, realistiniu situacijos îvertinimu, išmintingais ir atsakingais veiksmais grindžiamo optimizmo; 2) teikti pagalbą atrandant Absoliuto troškimu grindžiamus kasdieninių pasirinkimų kriterijus; 3) mokyti savo gyvenimo planuose neignoruoti neišvengiamos asmeninès kančios ir artimo žmogaus mirties išgyvenimo galimybès; 4) ugdyti nusiteikimą kovoti už teisingas vertybes, visų pirma už žmogaus orumą ir ateities meilę.

Dievo pažadą liudijantys realūs ženklai sukuria žmogui tvirtą atramą sąmoningai ir giliai vilčiai. Evangelija, kaip Geroji Naujiena, iš esmès yra tvirtos 
vilties pagrindas. Todèl krikščioniškuoju aspektu personalistinei vilties pedagogikai ypač svarbus yra religinis ugdymas. Personalistinëje vilties pedagogikoje būtina akcentuoti teologiniu dorybiu - vilties, tikejjimo ir meilès - neišardomą vienybę, todèl viltis neturi būti ugdoma atskirai nuo kitu teologiniu dorybių.

Vilties dorybès ugdytojas, traktuojantis pedagogini santyki kaip tarpasmeni- nę sąveiką, turi suteikti ugdytiniui intelektualinių vilties argumentu, t. y. sudaryti sąlygas mokiniui pasijusti mylimam ir priimtam asmeniui, pastebèti savo pažangą ir pajusti džiaugsmą dèl pasiekimų. Tai yra tikèjimo savimi ir pasitikejimo žmonėmis pagrindai. Tai, kaip bus ivvykdyti šie sudètingi pedagoginiai uždaviniai, priklauso nuo pedagogo kaip vilties žmogaus patikimumo.

\section{IŠVADOS}

1. Personalistinę vilties pedagogiką sudaro trys elementai - personalizmas, viltis ir pedagogika, kuriuos suvienija žmogaus gyvenimo prasmès paieška. Viltis, kaip žmogaus galimybių išraiška, iprasmina pedagoginę veiklą. Personalizmą su pedagogika sieja bendras siekis surasti prasmę. Taigi gyvenimo prasmè yra personalizmo, vilties ir pedagogikos sintezės pagrindas ir personalistinès vilties pedagogikos svarbiausias elementas. Logoterapijos teorija taip pat akcentuoja vilties svarbą žmogui ieškant gyvenimo prasmès ir ją išskleidžiant.

2. Dramatiškoje pasaulio situacijoje dabar (ir ateityje) reikalinga Vilties žinia. Sunkių iššūkių ir grèsmių akivaizdoje viltis yra ne paskata tiesiog apskaičiuoti galimybes ir grèsmes, o žmogaus atsakas i jas. Šiandien ieškoma būdu rasti bendrų, dialogą igalinančiu sąlyčio tašku tarp dviejų priešingų visuomenès polių tarp turinčių viltị Dieve, sąmoningai tikinčiu išskirtinai besirūpinančiu žmonijos Išganymu krikščionių ir nevilties kultūros bei vartotojiškumo ideologijos paveiktų žmoniu, kurie gerbia pasaulio teisinę tvarką ir saugo žmogaus teises, tačiau ju gyvenime vilties Dievo vietą užima iliuzinè viltis, kuri grindžiama mokslu ir pažanga, galejimu valdyti kuo daugiau materialiu vertybių, igyti valdžią ir galių ar patirti malonumų ir pan. Vilties principą norima pakeisti atsakomybès už savo gerovę principu, tačiau jei nèra vilties, didžiulio blogio pasaulyje akivaizdoje susidūrus su grèsmėmis, ši atsakomybè užleidžia vietą rezignacijai ir depresijai. Žmogiškajame lygmenyje pastebima tokia tendencija: kuo labiau krikščioniškoji viltis užleidžia savo poziciją visuomenejje, tuo labiau pastarojoje įsigali iliuzinès viltys arba neviltis. Tad išryškèja būtinybẻ liudyti krikščioniškąją viltį. I tai nukreiptas personalistinès vilties pedagogikos pagrindinis tikslas vilties dorybės ugdymas, kartu jis yra bendrojo auklejjimo esmè, pagrindinè priemone ir veiksmingumo salyga.

3. Personalistinès vilties pedagogikos siūlomas ugdymas apima ir gamtinį, ir antgamtini vilties lygmenis. Šios pedagogikos pagrindas yra iš Dievo kilęs nesumenkinamas ugdytinio orumas, buvimas Dievo vaiku ir galimybè laisvai apsispręsti. Svarbiausias personalistinès 
vilties pedagogikos principas yra, gerbiant vienas kito laisvę, asmens subjektyvumą, išskirtinumą ir kitoniškumą, kurti ugdytojo ir ugdytinio meilès dialogą. Vertinant iš būties perspektyvos, kūrybingos ir dinaminès personalistinès vilties pedagogikos uždaviniai yra nukreipti i gèrio prado žmoguje lavinimą. Vertybinis žmogaus matmuo suteikia personalistinei vilties pedagogikai prasmę, pasitikèjimas amžinosiomis vertybèmis ir galimybė pagal jas gyventi yra vilties esmè. Šioje pedagogikoje ugdytojo ir ugdytinio ugdomoji sąveika ne vienkryptè, o dvikryptè. Ji vyksta tarp dviejų neapibrèžiamų subjektu, todèl jos eiga sudètinga ir sunkiai planuojama.

4. Vilties dorybès ugdymas padeda sukurti pozityvu santyki su pasauliu, pačiu savimi ir kitais žmonèmis. Tobu-

\section{Literatūra}

Erikson Eric Homburger. 2004. Vaikystè ir visuome$n \dot{e}$. Vilnius: Kataliku pasaulio leidiniai.

Freire Paulo. 1994. Pedagogy of hope. London: Continuum.

Freire Paulo. 2007. Daring to dream. Boulder, CO: Paradigm.

Jonas Paulius II. 2003. Posinodinis apaštališkasis paraginimas Ecclesia in Europa. <http://www.lcn. lt/b_dokumentai/ap_paraginimai/ecclesia-in-europa.html> [žiūrèta 201902 09]

Komenskis Janas Amosas. 1975. Rinktiniai pedagoginiai raštai. Kaunas: Šviesa.

Maceina Antanas. 1991. Kultūros filosofijos ịvadas. Raštai, t. 1. Vilnius: Mintis. linant intelektualines galimybes, vilties dorybès ugdymas turi būti sutelktas ties sąmoningai priimtos ir išgyventos vilties liudijimu, tampančiu pagrindiniu vilties dorybės perdavimo metodu. Viltis teikia gyvenimui prasmę ir motyvus su meile kurti bendrajij gèri. Svarbiausius vilties ugdymo pagrindus suteikia asmens saviraiškos galimybių pristatymas, pagrįstas žmogaus, kaip asmens, sukurto pagal Dievo paveikslą ir panašuma, samprata. Krikščioniškasis ugdymas, atsiliepiantis i teologiškai apibūdinamą tikejjimo, vilties ir meilès dorybių integraluma, pakylëja žmogiškąją viltị virš biologinès mirties, nurodydamas, kad gyvenimo prasmé yra su meile kurti išliekamajji gèri savyje ir pasaulyje. Ugdant vilties dorybę svarbiausias yra ugdytojo, kaip vilties žmogaus, asmeninis liudijimas.

Paulius VI. 1975. Apaštališkasis paraginimas Evangelii nuntiandi. <http://eis.katalikai.lt/vb/popieziai/ paulius_vi/ap-paraginimai/1975-12-08_evangelii-nuntiandi> [žiūrèta 201903 05]

Popiežiškoji dvasinių pašaukimų globos draugija. 1999. Nauji pašaukimai naujajai Europai (In verbo tuo...). <http://www.lcn.lt/b_dokumentai/kiti_ dokumentai/nauji_pasaukimai.html.> [žiūrèta 201903 09]

Popiežius Pranciškus. 2014. Apaštališkasis paraginimas Evangelii gaudium. <http://www.baznycioszinios.lt/site/files/file/pdf/bzinios_2013-12.pdf> [Žiūrèta 201903 01]

Pukelis Kęstutis. 1998. Mokytoju rengimas ir filosofinès studijos. Kaunas: Versmè. 